\title{
СТАН СИСТЕМИ НІТРОГЕН (II) ОКСИДУ В ЩУРІВ 3 ПАРОДОНТИТОМ НА ФОНІ ГІПЕР- ТА ГІПОТИРЕОЗУ
}

Вступ. Запальні захворювання пародонта є однією з найбільш актуальних проблем стоматології, які мають соціальну значимість, що зумовлено високою розповсюдженістю, вираженими змінами в тканинах пародонта й організму хворого в цілому, ураженням осіб молодого віку.

Мета дослідження - дослідити функціональний стан системи нітроген (II) оксиду в щурів з пародонтитом без супутньої патології і на фроні гіпер- та гіпотиреозу.

Методи дослідження. Дослідження проведено на 48 білих нелінійних щурах-самцях. Сумарну активність NO-синтази визначали колориметрично за кількістю нітратів і нітритів, утворених в інкубаційному середовищі. Загальний вміст нітратів і нітритів визначали за методом Гріса.

Результати й обговорення. Експериментальний пародонтит супроводжувався підвищенням загальної активності NO-синтази в гомогенаті тканин пародонта у 2,2 раза відносно контролю. Загальний вміст нітратів і нітритів у сироватці тварин з пародонтитом зростав на 46,2 \%, а в гомогенаті тканин пародонта - на 74,7 \% порівняно з контролем. У щурів з пародонтитом на фоні гіпертиреозу активність NO-синтази збільшувалася в 3,9 раза відносно контрольної групи тварин і на 75,9 \% перевищувала показник щурів з пародонтитом без супутньої патології. У тварин з пародонтитом на фроні гіпотиреозу активність NO-синтази на 29,6 \% перевищувала показник щурів з пародонтитом без супутньої патології та у 2,9 раза - показник контролю.

Висновки. Експериментальний пародонтит супроводжується вираженим підвищенням інтенсивності нітроксидергічних процесів як у гомогенаті тканин пародонта, так і в крові. Дисбаланс тиреоїдних гормонів збільшує синтез нітроген (II) оксиду при експериментальному пародонтиті, особливо виражено при гіпертиреозі.

КЛЮЧОВІ СЛОВА: пародонтит; тиреоїдні гормони; нітроген (II) оксид.

ВСТУП. Запальні захворювання пародонта $€$ однією з найбільш актуальних проблем стоматології, які мають соціальну значимість, що зумовлено високою розповсюдженістю, вираженими змінами в тканинах пародонта й організму хворого в цілому, ураженням осіб молодого віку [1]. Багато років існує тенденція до більш раннього виникнення даного захворювання і його агресивного перебігу [2].

В останні роки, поряд з відомими концепціями патогенезу запальних і запально-дистрофічних захворювань пародонта, значну увагу приділяють активації пероксидного окиснення ліпідів. Відомо, що неконтрольовані реакції пероксидного окиснення ліпідів здатні не тільки призводити до порушення обмінних процесів, а й викликати структурні зміни в тканинах, пригнічувати захисні механізми організму, що, у свою чергу, сприяє активації мікробів, які колонізують ясна і пародонтальні кишені [3]. Крім того, дове(c) В. В. щерба, М. М. Корда, 2018. деним є вплив пероксидного окиснення на розвиток пародонтиту через вільнорадикальну деполімеризацію мукополісахаридів і пероксидну деструкцію еластичних волокон, що спричиняє атеросклероз судин пародонта $[4,5]$.

Крім активних фрорм кисню, в останні роки дослідники все більше уваги приділяють і активним формам азоту, зокрема нітроген (II) оксиду (NO), та його ролі як універсального трансмітера в розвитку різних патологічних станів. Наявність одного неспареного електрона на зовнішній т-орбіталі надає NO високу реакційну здатність [6].

Мета дослідження - дослідити функціональний стан системи нітроген (II) оксиду в щурів 3 пародонтитом без супутньої патології і на фроні гіпер- та гіпотиреозу.

МЕТОДИ ДОСЛІДЖЕННЯ. Дослідження проведено на 48 білих безпородних статевозрілих щурах-самцях масою 180-200 г, яких утримували на стандартному раціоні віварію. 
Піддослідних тварин було поділено на такі групи. До 1-ї групи входили контрольні тварини, яким вводили внутрішньошлунково $1 \%$ розчин крохмалю ( $\mathrm{n}=12)$. Щурам 2-ї групи (з моделлю пародонтиту) протягом 2-х тижнів через день вводили в тканини ясен по 40 мікролітрів (1 мг/мл) ліпополісахариду E. Coli ("Sigma-Aldrich", США) (n=12) [7]. До 3-ї групи належали тварини з пародонтитом на фоні гіпертиреозу. Для моделювання експериментальної гіперсункції щитоподібної залози щурам щоденно внутрішньошлунково вводили L-тироксин на $1 \%$ розчині крохмалю з розрахунку 10 мкг/добу на 100 г маси протягом 21-ї доби ( $\mathrm{n}=12)$ [8]. Починаючи з 8-ї доби експерименту, тваринам вводили в тканини ясен ліпополісахарид протягом 2-х тижнів. До 4-ї групи входили щури з пародонтитом на фоні гіпотиреозу. 3 метою моделювання експериментальної гіпофункції щитоподібної залози тваринам щоденно внутрішньошлунково вводили мерказоліл на $1 \%$ розчині крохмалю з розрахунку 1 мг/добу на 100 г маси протягом 21-ї доби ( $\mathrm{n=12}$ [8]. Починаючи з 8-ї доби експерименту, щурам вводили в тканини ясен ліпополісахарид протягом 2-х тижнів. Евтаназію тварин здійснювали шляхом кровопускання за умов тіопентал-натрієвого наркозу на 22-гу добу від початку досліду.

Усі маніпуляції з експериментальними щурами проводили з дотриманням правил відповідно до Європейської конвенції про захист хребетних тварин, що використовуються для дослідних та інших наукових цілей [9].

Для досліджень використовували сироватку крові та гомогенат тканин пародонта.

Сумарну активність NO-синтази (NOS) у тканині пародонта визначали колориметрично за кількістю нітратів і нітритів, утворених в інкубаційному середовищі, що містило 40 мМ трис$\mathrm{HCl}$-буфер $(\mathrm{pH}=7,9)$, гомогенат тканин пародонта (1 мг білка/мл), $4 \mu \mathrm{M}$ ФАД, $4 \mu \mathrm{M} \mathrm{H}_{4}$-біоптерин, 3 mM дитіотреїтол і 1 мM L-аргінін. Реакцію ініціювали шляхом додавання НАДФН (2 mM), i середовище інкубували протягом 3 год при температурі $37^{\circ} \mathrm{C}$ [10]. Кількість утворених нітратів і нітритів визначали, як описано нижче. Загальний вміст нітратів і нітритів $\left(\mathrm{NO}_{x}\right)$ визначали за методом Гріса після відновлення їх за допомогою кадмію [11]. Перед дослідом 2-3 г гранул металічного кадмію промивали 100 мл бідистильованої води. Супернатант відкидали, і гранули промивали двічі у 50 мл 0,5 M HCl. Кадмій знову промивали бідистильованою водою і використовували в експерименті протягом 20 хв. До 0,4 мл сироватки крові, гомогенату тканин пародонта або інкубаційної суміші (для визначення сумарної активності NOS) додавали 1,6 мл 50 мM карбонатного буфрера $(\mathrm{pH}=9,0)$ і невелику кількість ( 0,4 г) гранул кадмію. Пробірки інкубували при кімнатній температурі протягом 1 год, періодично помішуючи. Потім додавали 0,4 мл 0,35 M $\mathrm{NaOH} \mathrm{i} \mathrm{1,6} \mathrm{мл} 120$ мМ сульфрату цинку. Пробірки залишали на 10 хв для депротоїнізації, осад відцентрисруговували протягом 15 хв при 9000 об./хв. 1,5 мл надосадової рідини змішували 3 1,5 мл реактиву Гріса (0,75 мл 1 \% сульсраніламіду, приготовленого на $3 \mathrm{M} \mathrm{HCl}$, і 0,1 \% $\mathrm{N}$-насртилетилендіаміну, приготовленого на воді) й інкубували 10 хв при кімнатній температурі. Екстинкцію визначали на спектрофотометрі СФ-46 при довжині хвилі 546 нм. Розрахунки проводили за калібрувальним грасріком, використовуючи як стандарт нітрит натрію.

Статистичну обробку цисррових даних здійснювали за допомогою програмного забезпечення Excel (Microsoft, США) i STATISTICA 6.0 (Statsoft, США) з використанням непараметричних методів оцінки одержаних даних. Для всіх показників розраховували значення середньої арифрметичної вибірки (М), її дисперсії і помилки середньої $(m)$. Достовірність різниці значень між незалежними кількісними величинами визначали за допомогою критерію Манна-Уїтні. Зміни вважали статистично достовірними при р<0,05.

РЕЗУЛЬТАТИ Й ОБГОВОРЕННЯ. РезУЛЬтаТИ наших досліджень показали, що інтенсивність нітроксидергічних процесів достовірно збільшувалася у тварин усіх експериментальних груп (табл.).

При моделюванні пародонтиту ліпополісахаридом загальна активність NO-синтази в гомогенаті тканин пародонта у 2,2 раза $(p<0,001)$ підвищувалася відносно контрольної групи тварин. Очевидно, активацією NOS можна пояснити отримані результати, які свідчать про достовірне збільшення вмісту метаболітів нітроген (II) оксиду - нітратів і нітритів - у сироватці крові й пародонті щурів, яким вводили ліпополісахарид. Зокрема, вміст $\mathrm{NO}_{x}$ у сироватці тварин 3 пародонтитом зростав на 46,2 \% $(p<0,001)$ порівняно з контролем. Так само даний показник підвищувався і в гомогенаті тканин пародонта на $74,7 \%(p<0,001)$.

Поряд із посиленим продукуванням вільних радикалів оксигену важливим патогенетичним механізмом розвитку запалення у тканинах пародонта $€$ нітрооксидативний стрес [12-14]. Було показано, що при пародонтиті, індукованому ендотоксином грамнегативної мікросрлори, достовірно зростає загальна активність синтази нітроген (II) оксиду в пародонті та збільшується вміст його метаболітів - нітратів і нітритів - у сироватці крові й тканинах пародонта. Відомо, 
Таблиця - Активність NO-синтази у тканинах пародонта і вміст метаболітів нітроген (II) оксиду в сироватці крові й гомогенаті тканин пародонта щурів з пародонтитом без супутньої патології і на фроні гіпер- та гіпотиреозу ( $\mathrm{M} \pm \mathrm{m}, \mathrm{n}=12)$

\begin{tabular}{|c|c|c|c|c|}
\hline \multirow[b]{2}{*}{ Показник } & \multicolumn{4}{|c|}{ Група тварин } \\
\hline & контроль & пародонтит & $\begin{array}{l}\text { пародонтит на фроні } \\
\text { гіпертиреозу }\end{array}$ & $\begin{array}{l}\text { пародонтит на фроні } \\
\text { гіпотиреозу }\end{array}$ \\
\hline \multicolumn{5}{|c|}{ Супернатант гомогенату пародонта } \\
\hline $\begin{array}{l}\text { NO-синтаза, } \\
\text { нмоль/(хв·мг білка) }\end{array}$ & $0,24 \pm 0,02$ & $\begin{array}{c}0,54 \pm 0,05 \\
p_{1}<0,001\end{array}$ & $\begin{array}{l}0,95 \pm 0,07 \\
p_{1}<0,001 \\
p_{2}<0,001\end{array}$ & $\begin{array}{c}0,70 \pm 0,05 \\
p_{1}<0,001 \\
p_{3}<0,05 \\
p_{4}<0,02\end{array}$ \\
\hline $\mathrm{NO}_{\mathrm{x}}$, мМоль/кг & $0,79 \pm 0,03$ & $\begin{array}{c}1,32 \pm 0,05 \\
p_{1}<0,001\end{array}$ & $\begin{array}{c}1,95 \pm 0,12 \\
p_{1}<0,001 \\
p_{2}<0,001\end{array}$ & $\begin{array}{c}1,51 \pm 0,07 \\
p_{1}<0,001 \\
p_{3}<0,05 \\
p_{4}<0,01\end{array}$ \\
\hline \multicolumn{5}{|c|}{ Сироватка крові } \\
\hline $\mathrm{NO}_{\text {х }}$, ммоль/л & $1,84 \pm 0,08$ & $\begin{array}{c}2,69 \pm 0,07 \\
p_{1}<0,001\end{array}$ & $\begin{array}{c}3,70 \pm 0,08 \\
p_{1}<0,001 \\
p_{2}<0,001\end{array}$ & $\begin{array}{c}3,00 \pm 0,12 \\
p_{1}<0,001 \\
p_{3}<0,05 \\
p_{4}<0,001\end{array}$ \\
\hline
\end{tabular}

Примітки:

1. p $_{1}$ вірогідність відмінностей між контрольною та експериментальними групами.

2. $\mathrm{p}_{2}$ - вірогідність відмінностей між групою тварин з пародонтитом і групою щурів з пародонтитом на фроні гіпертиреозу.

3. $\mathrm{p}_{3}$ - вірогідність відмінностей між групою тварин з пародонтитом і групою щурів з пародонтитом на фроні гіпотиреозу.

4. $p_{4}$ - вірогідність відмінностей між групою тварин з пародонтитом на фроні гіпертиреозу і групою щурів 3 пародонтитом на тлі гіпотиреозу.

що сам ліпополісахарид та медіатори запалення, які утворюються під його впливом у тканинах пародонта, виражено активують індуцибельну форму NOS, у результаті чого утворюється надмірна кількість NO [15]. Серед медіаторів запалення, які продукуються у відповідь на інфрікування тканин пародонта, основними є фрактор некрозу пухлин $\alpha$, інтерлейкіни $1 \beta$ та 6 [16].

Отже, очевидно, підвищення загальної активності NO-синтази в гомогенаті тканин пародонта щурів з пародонтитом і синтез надмірної кількості нітроген (II) оксиду (збільшення вмісту $\mathrm{NO}_{\mathrm{x}}$ ), що спостерігали в наших дослідженнях, зумовлені саме гіперекспресією індуцибельної форми даного ферменту під впливом прозапальних цитокінів.

Окисний стрес і запалення тісно взаємопов'язані, оскільки окисний стрес може викликати запалення, яке, у свою чергу, може спричинити окисний стрес. Як окисний стрес, так і запалення зумовлюють пошкодження клітин. Запальні стани внаслідок виділення прозапальних цитокінів підвищують експресію індуцибельної NOS у макрофрагах та гладком'язових клітинах. Спочатку вона використовується для компенсації зниженої активності ендотеліальної NOS за рахунок окисного стресу, однак водночас прозапальні цитокіни, головним чином, фрактор некрозу пухлин а та С-реактивний білок, активізують НАДФН-оксидазу поліморфноядерних лімфроцитів, яка, у свою чергу, генерує супероксиданіонрадикал. Надлишкова кількість NO, що генеру- ється індуцибельною NOS, буде взаємодіяти із супероксиданіонрадикалом 3 утворенням пероксинітриту, який при високих концентраціях піддається гомолітичному чи гетеролітичному розпаду, що супроводжується генерацією каскаду високотоксичних окиснювальних середників. Ці реактивні сполуки можуть окиснювати ліпіди, пошкоджувати клітинні мембрани, окиснювати тіолові групи білків, що призводить до руйнування клітин і білків та маніфестації запального процесу [17, 18].

Крім того, патологічна активність індуцибельної NOS може підвищувати активність аргінази. Аргіназа зменшує утворення NO, конкуруючи з ендотеліальною NOS за L-аргінін. Показано, що підвищена активність аргінази збільшує і сприяє утворенню супероксиданіона шляхом роз'єднання NOS у плаценті жінок із прееклампсією [19], що формує "хибне коло” [18].

Необхідно вказати, що NO також може виконувати корисну функцію при пародонтиті як неспециорічний фрактор захисту від бактерій. Вироблення макрофрагами NO при запаленні пародонта стимулює разом 3 іншими радикалами реакції фрагоцитозу. Водночас дефіцит NO сприяє розмноженню збудників у тканинах пародонта, що призводить до хронізації патологічного процесу [20].

У щурів з пародонтитом на фроні гіпертиреозу активність NO-синтази у гомогенаті тканин пародонта збільшувалася в 3,9 раза $(p<0,001)$ відносно контрольної групи тварин і на 75,9 \% 
( $<<0,001)$ перевищувала показник щурів з пародонтитом без супутньої патології. У тварин 3 пародонтитом на фоні гіпотиреозу активність NO-синтази на 29,6 \% $(p<0,05)$ перевищувала показник щурів 3 пародонтитом без супутньої патології та у 2,9 раза $(\mathrm{p}<0,001)$ - показник контролю. При порівнянні активності NO-синтази у гомогенаті тканин пародонта гіпер- та гіпотиреоїдних тварин встановлено ії достовірне переважання на 35,7 \% у гіпертиреоїдних щурів.

Моделювання пародонтиту на фоні гіпертиреозу призвело до достовірного зростання рівня $\mathrm{NO}_{\text {× }}$ у сироватці крові у 2,0 рази порівняно 3 контролем. Ще більшою мірою (у 2,5 раза) даний показник підвищувався в гомогенаті тканин пародонта. Необхідно відзначити, що як у крові, так і в пародонті щурів даної групи вміст $\mathrm{NO}_{x}$ був достовірно вищим, ніж у тварин з пародонтитом без тиреоїдної диссрункції. Зокрема, в сироватці крові щурів з поєднаною патологією концентрація нітратів і нітритів зростала, порівняно з такою у тварин, яким вводили лише ліпополісахарид, на $37,5 \%(p<0,001)$. У гомогенаті тканин пародонта вміст $\mathrm{NO}_{x}$ збільшувався, порівняно $з$ групою тварин, яким моделювали пародонтит, на $47,7 \%(\mathrm{p}<0,001)$.

Аналогічну тенденцію спостерігали і в гіпотиреоїдних тварин. Вміст $\mathrm{NO}_{x}$ у сироватці крові зростав на $63,0 \%(p<0,001)$, а в гомогенаті тканин пародонта - на 91,1 \% $(\mathrm{p}<0,001)$ порівняно з контролем. При цьому він перевищував показник тварин з пародонтитом без тиреоїдної дисфункції: на $11,5 \%(p<0,05)$ - у сироватці крові та на $14,4 \%(p<0,05)$ - у гомогенаті тканин пародонта.

Ці дані свідчать про те, що при дії токсинів грамнегативної мікросрлори на пародонт тварин з гіпер- чи гіпотиреозом індуцибельна фрорма NO-синтази індукується більшою мірою, ніж при дії токсинів на пародонт щурів без супутньої патології. У цьому контексті можна припустити, що порушення обміну NO, поряд з окисним стресом, $є$ однією з ключових ланок у патогенетичних перебудовах у тварин із запальними процесами пародонта, що перебігають на фоні тиреоїдної диссрункції.

Тиреоїдні гормони самі можуть діяти як оксиданти і спричинювати пошкодження ДНК, імовірно, через наявність френольної групи [21]. Крім того, інші механізми [22] можуть бути задіяні, зокрема підвищення експресії гена NO-синтази 3 гіперпродукуванням NO та активацією печінкового транскрипційного ядерного фрактора кВ 3 подальшим зростанням рівня цитокінів, що зумовлює гіперпродукування активних форм оксигену.

A. Quesada та співавт. визначали активність NOS у серці (лівий і правий шлуночки), судинах (аорта і порожниста вена) та нирках (кірковий і мозковий шари) еутиреоїдних, гіпертиреоїдних та гіпотиреоїдних щурів. Окрім правого шлуночка, активність NOS у тканинах гіпертиреоїдних тварин була підвищеною відносно еутиреоїдної групи. У групі гіпотиреоїдних щурів результати виявилися неоднорідними. Активність NOS була значно збільшеною в обох шлуночках, але значно зменшеною в аорті, тоді яку порожнистій вені та нирках даний показник достовірно не змінився щодо еутиреоїдної групи [23].

Гетерогенна картина активності NOS у тканинах гіпотиреоїдних щурів може бути результатом змін вираження різних ізоформ NOS або навіть пов'язана зі змінами активності NOS у субклітинних срракціях. М. C. Carreras та співавт. відзначили, що при гіпотиреозі збільшується активність мітохондріальної NOS у печінці та скелетних м'язах. При цьому було виявлено зворотний кореляційний зв'язок між активністю NOS та концентрацією трийодтироніну в сироватці крові [24]. Ү. Uеta та співавт. повідомляють про знижену активність NOS у гіпоталамусі за умови гіпотиреозу [25].

Механізм зростання активності NOS у тканинах гіпертиреоїдних щурів точно не відомий, що може бути пов'язано з компенсаторною реакцією на високий артеріальний тиск у цих тварин, підвищеним виділенням вазоактивних речовин, таких, як ангіотензин II та ендотелін, які збільшують продукцію NO, або з механізмом ендотеліального напруження, викликаного гіпердинамічною циркуляцією цих щурів [23].

ВИСНОВКИ. Експериментальний пародонтит супроводжується вираженим підвищенням інтенсивності нітроксидергічних процесів як у гомогенаті тканин пародонта, так і в крові. Дисбаланс тиреоїдних гормонів збільшує синтез нітроген (II) оксиду при експериментальному пародонтиті, особливо виражено - при гіпертиpeозi. 


\section{СПИСОК ЛІТЕРАТУРИ}

1. Сакварелидзе И. Роль свободно-радикального окисления и антиоксидантной защиты в развитии воспалительных процессов в пародонте в женской популяции / И. Сакварелидзе // Актуальные опросы Женского Здоровья. - 2014. - № 5. - С. 64-76.

2. Успенская О. А. Изменения биохимических показателей крови при лечении быстропрогрессирующего пародонтита / О. А. Успенская, Е.С.Качесова // Проблемы стоматологии. -2017. - № 13 (2). - С. 33-38.

3. Савельева Н. Н. Состояние системы перекисного окисления липидов и антиоксидантной защиты у больных хроническим генерализованным пародонтитом I-II степени тяжести, сочетающегося с паразитозами / Н. Н. Савельева // Journal of Education, Health and Sport. - 2015. - № 5 (12). - C. 465-476.

4. Шпуліна О. О. Сучасні основи патогенезу пародонтиту (огляд літератури) / О. О. Шпуліна // Укр. мед. альм. - 2004. - № 6. - С. 189-194.

5. Коваленко В. М. Молекулярно-генетичні особливості фрункціонування параоксонази та ії значення в розвитку серцево-судинної патології / В.М.Коваленко, О. Б. Кучменко, Л. С. Мхітарян // Укр. кардіол. журн. - 2014. - № 5. - С. 105-116.

6. Роль оксида азота в процессах свободнорадикального окисления / А. Г. Соловьева, В. Л. Кузнецова, С. П. Перетягин [и др.] // Вестн. Российской военно-медицинской академии. - 2016. - № 1 (53). С. 228-233.

7. Моисеева Е. Г. Метаболический гомеостаз и имунная реактивность организма в динамике воспаления в тканях пародонта (экспериментальное исследование) : автореф. дисс. на соискание учен. степени доктора мед. наук / Е. Г. Моисеева. - М., 2008. $45 \mathrm{c}$.

8. Ратушненко В. О. Функціональна роль тіол-дисульфрідної системи при експериментальному гіпо- і гіпертиреозі / В. О. Ратушненко // Одес. мед. журн. 2010. - № 2 (118). - C. 17-20.

9. European convention for the protection of vertebrate animals used for experimental and other scientific purposes: Council of Europe. - Strasbourg. - 1986. № 123. - P. 52.

10. $N^{\omega}$-Hydroxy-L-arginine is an intermediate in the biosynthesis of nitric oxide from L-arginine / D. Stuehr, N. S. Kwon, C. Nathan, O. Griffiths // Journal of Biological Chemistry. - 1991. - 266. - P. 6259-6263.

11. Aspectrophotometric method for the direct detection and quantitation of nitric oxide, nitrite, and nitrate in cell culture media / L. Ridnour, J. E. Sim, M. Hayward [et al.] // Analytical Biochemistry - 2000. - 281. P. 223-229.

12. Nitric oxide production, systemic inflammation and lipid metabolism in periodontitis patients: possible gender aspect / O. Andrukhov, H. Haririan, K. Bertl [et al.] // J. Clin. Periodontol. - 2013. - 40, No. 10. P. 916-923.
13. Comparison of the salivary and the serum nitric oxide levels in chronic and aggressive periodontitis: a biochemical study / N. M. Sundar, V. Krishnan, S. Krishnaraj [et al.] // J. Clin. Diagn. Res. - 2013. - 7, No. 6. P. 1223-1227.

14. Periodontal disease, periodontal treatment and systemic nitric oxide in dogs / A. Nemec, F. J. Verstraete, A. Jerin [et al.] // Res. Vet. Sci. - 2013. - 94, No. 3. P. 542-544.

15. Antimicrobial peptides and nitric oxide production by neutrophils from periodontitis subjects / F. S. Mariano, A. P. Campanelli, F. H. Jr. Nociti [et al.] // Brazilian Journal of Medical and Biological Research. - 2012. - 45, No. 11. - P. 1017-1024.

16. Effect of resveratrol and modulation of cytokine production on human periodontal ligament cells / A. Rizzo, N. Bevilacqua, L. Guida [et al.] // Cytokine. - 2012. 60, No. 1. - P. 197-204.

17. Rubbo H. Peroxynitrite-mediated lipid oxidation and nitration: mechanisms and consequences / H. Rubbo, A. Trostchansky, V. B. O'Donnell // Archives of Biochemistry and Biophysics. - 2009. - 484, No. 2. P. 167-172.

18. Siti H. N. The role of oxidative stress, antioxidants and vascular inflammation in cardiovascular disease (a review) / H. N. Siti, Y. Kamisah, J. Kamsiah // Vascular Pharmacology. - 2015. - 71. - P. 40-56.

19. Sankaralingam S. Arginase contributes to endothelial cell oxidative stress in response to plasma from women with preeclampsia / S. Sankaralingam, H. Xu, S.T. Davidge // Cardiovascular Research. - 2010. 85 (1). - P. 194-203.

20. Колодницька Г. Б. Перебіг ліпополісахаридного запалення ясен при інсулінозалежному цукровому діабеті / Г. Б. Колодницька, М. М. Корда // Мед. хімія. 2011. - 13, № 3 (48). - C. 91-95.

21. Dobrzy'nska M. M. Antioxidants modulate thyroid hormone and noradrenaline-induced DNA damage in human sperm / M. M. Dobrzy'nska, A. Baumgartner, D. Anderson // Mutagenesis. - 2004. - 19 (4). - P. 325330.

22. Venditti P. Thyroid hormone-induced oxidative stress / P. Venditti, S. DiMeo // Cellular and Molecular Life Sciences. - 2006. - 63 (4). - P. 414-434.

23. Nitric oxide synthase activity in hyperthyroid and hypothyroid rats / A. Quesada, J. Sainz, R. Wangensteen [et al.] // European Journal of Endocrinology. - 2002. 147. - P. 117-122.

24. Modulation of liver mitochondrial NOS is implicated in thyroid-dependent regulation of $\mathrm{O}_{2}$ uptake I M. C. Carreras, J. G. Peralta, D. P. Converso [et al.] // American Journal of Physiology. - 2001. - 281. P. H2282- H2288.

25. Hypothalamic nitric oxide synthase gene expression is regulated by thyroid hormones / Y. Ueta, A. Levy, H. S. Chowdrey S. L. Lightman // Endocrinology. - 1995. - 136. - P. 4182-4187. 


\section{REFERENCES}

1. Sakvarelidze, I. (2014). Rol svobodno-radikalnogo okisleniya i antioksidantnoy zashchity $\mathrm{v}$ razvitii vospalitelnykh protsessov $v$ parodonte $v$ zhenskoy populyatsii [The role of free radical oxidation and antioxidant protection in the development of inflammatory processes in the periodontium in the female population]. Aktualnyye oprosy Zhenskogo Zdorovya - Actual Surveys of Women's Health, 5, 64-76 [in Russian].

2. Uspenskaya, O.A., \& Kachesova, Ye.S. (2017). Izmeneniya biokhimicheskikh pokazateley krovi pri lechenii bystroprogressiruyushchego parodonta [Changes in biochemical parameters of blood in the treatment of rapidly progressing periodontitis]. Problemy stomatologii - Problems of Dentistry, 13 (2), 33-38 [in Russian].

3. Saveleva, N.N. (2015). Sostoyaniye sistemy perekisnogo okisleniya lipidov i antioksidantnoy zashchity u bolnykh khronicheskim generalizovannym parodontitom I-II stepeni tyazhesti, sochetayushchegosya s parazitozami [The state of the system of lipid peroxidation and antioxidant protection in patients with chronic generalized periodontitis of I-II severity, combined with parasitosis]. Journal of Education, Health and Sport, 5, 12, 465-476 [in Russian].

4. Shpulina, O.O. (2004). Suchasni osnovy patohenezu parodontytu (ohliad literatury) [Modern foundations of pathogenesis of periodontitis (review of literature)]. Ukrainskyi medychnyi almanakh - Ukrainian Medical Almanac, 6, 189-194 [in Ukrainian].

5. Kovalenko, V.M., Kuchmenko, O.B., \& Mkhitarian, L.S. (2014). Molekuliarno-henetychni osoblyvosti funktsionuvannia paraoksonazy ta yii znachennia v rozvytku sertsevo-sudynnoi patolohii [Molecular genetic peculiarities of paraoxonase function and its importance in the development of cardiovascular pathology]. Ukrainskyi kardiolohichnyi zhurnal - Ukrainian Cardiology Journal, 5, 105-116 [in Ukrainian].

6. Solovyeva, A.G., Kuznetsova, V.L., Peretyagin, S.P., Didenko, N.V., \& Dudar, A.I. (2016). Rol oksida azota v protsessakh svobodnoradikalnogo okisleniya [The role of nitric oxide in free-radical oxidation processes]. Vestnik Rossiyskoy voyenno-meditsinskoy akademii - Bulletin of the Russian Military Medical Academy, 1 (53), 228-233 [in Russian].

7. Moyseeva, E.G. (2008). Metabolicheskiy gomeostaz i imunnaya reaktivnost organizma $v$ dinamike vospaleniya $v$ tkanyakh parodonta [Metabolic homeostasis and immune reactivity of the organism in the dynamics of inflammation in periodontal tissues]. Extended abstract of Doctor's thesis. Moscow [in Russian].

8. Ratushnenko, V.O. (2010). Funktsionalna rol tioldysulfidnoi systemy pry eksperymentalnomu hipo- i hipertyreozi [Functional role of thiol-disulphide system in experimental hypo- and hyperthyroidism]. Odeskyi medychnyi zhurnal - Odesa Medical Journal, 2 (118), 17-20 [in Ukrainian].

9. European convention for the protection of vertebrate animals used for experimental and other scientific purposes: Council of Europe (1986). Strasbourg, 123, 52.

10. Stuehr, D., Kwon, N.S., Nathan, C., \& Griffiths O. (1991). $\mathrm{N}^{\omega}$-Hydroxy-L-arginine is an intermediate in the biosynthesis of nitric oxide from L-arginine. Journal of Biological Chemistry, 266, 6259-6263.

11. Ridnour, L., Sim, J.E., \& Hayward M. (2000). A spectrophotometric method for the direct detection and quantitation of nitric oxide, nitrite, and nitrate in cell culture media. Analytical Biochemistry, 281, 223-229.

12. Andrukhov, O., Haririan, H. \& Bertl, K. (2013). Nitric oxide production, systemic inflammation and lipid metabolism in periodontitis patients: possible gender aspect. Journal of Clinical Periodontology, 40, 10, 916923.

13. Sundar, N.M., Krishnan, V. \& Krishnaraj, S. (2013). Comparison of the salivary and the serum nitric oxide levels in chronic and aggressive periodontitis: a biochemical study. Journal of Clinical and Diagnostic Research, 7, 6, 1223-1227.

14. Nemec, A., Verstraete, F.J. \& Jerin, A. (2013). Periodontal disease, periodontal treatment and systemic nitric oxide in dogs. Research in Veterinary Science, $94,3,542-544$

15. Mariano, F.S., Campanelli, A.P., \& Nociti, F.H.Jr. (2012). Antimicrobial peptides and nitric oxide production by neutrophils from periodontitis subjects. Brazilian Journal of Medical and Biological Research, 45, 11, 10171024.

16. Rizzo, A., Bevilacqua, N. \& Guida, L. (2012). Effect of resveratrol and modulation of cytokine production on human periodontal ligament cells. Cytokine, 60, 1, 197-204.

17. Rubbo, H., Trostchansky, A. \& O'Donnell, V.B. (2009). Peroxynitrite-mediated lipid oxidation and nitration: mechanisms and consequences. Archives of Biochemistry and Biophysics, 484, 2, 167-172.

18. Siti, H.N., Kamisah, Y. \& Kamsiah, J. (2015). The role of oxidative stress, antioxidants and vascular inflammation in cardiovascular disease (a review). Vascular Pharmacology, 71, 40-56.

19. Sankaralingam, S., Xu, H. \& Davidge, S.T. (2010). Arginase contributes to endothelial cell oxidative stress in response to plasma from women with preeclampsia. Cardiovascular Research, 85 (1), 194-203.

20. Kolodnytska H.B. \& Korda M.M. (2011). Perebih lipopolisakharydnoho zapalennia yasen pry insulinozalezhnomu tsukrovomu diabeti [Flow of lipopolysaccharide gum inflammation in insulin-dependent diabetes mellitus]. Medychna khimiia - Medical Chemistry, 13 (3), 91-95 [in Ukrainian].

21. Dobrzynska, M.M., Baumgartner, A. \& Anderson, D. (2004). Antioxidants modulate thyroid hormone and noradrenaline-induced DNA damage in human sperm. Mutagenesis, 19 (4), 325-330.

22. Venditti, P. \& DiMeo, S. (2006). Thyroid hormoneinduced oxidative stress. Cellular and Molecular Life Sciences, 63 (4), 414-434.

23. Quesada, A., Sainz, J., Wangensteen, R., Rodriguez-Gomez, I., Vargas, F. \& Osuna, A. (2002). Nitric oxide synthase activity in hyperthyroid and hypothyroid rats. European Journal of Endocrinology, 147, 117-122.

24. Carreras, M.C., Peralta, J.G., Converso, D.P., Finoccchietto, P.V., Rebagliatti, I. \& Zaninovich, A.A. (2001). Modulation of liver mitochondrial NOS is implicated in thyroid-dependent regulation of $\mathrm{O} 2$ uptake. American Journal of Physiology, 281, 2282-2288.

25. Ueta, Y., Levy, A., Chowdrey, H.S. \& Lightman, S.L. (1995). Hypothalamic nitric oxide synthase gene expression is regulated by thyroid hormones. Endocrinology, 136, 4182-4187. 


\section{СОСТОЯНИЕ СИСТЕМЫ НИТРОГЕН (II) ОКСИДА У КРЫС С ПАРОДОНТИТОМ НА ФОНЕ ГИПЕР- И ГИПОТИРЕОЗА}

\section{Резюме}

Вступление. Воспалительные заболевания пародонта являются одной из наиболее актуальных проблем стоматологии, которые имеют социальную значимость, что обусловлено высокой распространенностью, выраженными изменениями в тканях пародонта и организма больного в целом, поражением лиц молодого возраста.

Цель исследования - исследовать фрункциональное состояние системы нитроген (II) оксида у крыс с пародонтитом без сопутствующей патологии и на фроне гипер- и гипотиреоза.

Методы исследования. Исследование проведено на 48 белых нелинейных крысах-самцах. Суммарную активность NO-синтазы определяли колориметрически по количеству нитратов и нитритов, образованных в инкубационной среде. Общее содержание нитратов и нитритов определяли по методу Гриса.

Результаты и обсуждение. Экспериментальный пародонтит сопровождался повышением общей активности NO-синтазы в гомогенате тканей пародонта в 2,2 раза относительно контроля. Общее содержание нитратов и нитритов в сыворотке животных с пародонтитом возрастало на 46,2 \%, а в гомогенате тканей пародонта - на 74,7% по сравнению с контролем. У крыс с пародонтитом на фроне гипертиреоза активность NO-синтазы увеличивалась в 3,9 раза относительно контрольной группы животных и на 75,9 \% превышала показатель крыс с пародонтитом без сопутствующей патологии. У животных с пародонтитом на фроне гипотиреоза активность NO-синтазы на 29,6 \% превышала показатель крыс с пародонтитом без сопутствующей патологии и в 2,9 раза - показатель контроля.

Выводы. Экспериментальный пародонтит сопровождается выраженным повышением интенсивности нитроксидергических процессов как в гомогенате тканей пародонта, так и в крови. Дисбаланс тиреоидных гормонов увеличивает синтез нитроген (II) оксида при экспериментальном пародонтите, особенно выраженно - при гипертиреозе.

КЛЮЧЕВЫЕ СЛОВА: пародонтит; тиреоидные гормоны; нитроген (II) оксид.

V. V. Shcherba, M. M. Korda I. HORBACHEVSKY TERNOPIL STATE MEDICAL UNIVERSITY

\section{THE STATE OF THE NITROGEN (II) OXIDE SYSTEM IN RATS WITH PERIODONTITIS ON THE BACKGROUND OF HYPER- AND HYPOTHYROIDISM}

\section{Summary}

Introduction. Inflammatory periodontal disease is one of the most urgent problems of dentistry, which has a social significance due to the high prevalence, pronounced changes in the tissues of the periodontal disease and the body of the patient as a whole, and the defeat of young people.

The aim of the study - to investigate the functional state of the nitrogen (II) oxide system in rats with periodontitis without concomitant pathology and against the background of hyper- and hypothyroidism.

Research Methods. The study was carried out on 48 white non-linear male rats. The total activity of NO-synthase (NOS) was determined colorimetrically by the number of formed nitrates and nitrites in the incubation medium. The total content of nitrates and nitrites (NOx) was determined by the Gris method.

Results and Discussion. Experimental periodontitis is accompanied by increased general activity of NOsynthase in periodontal tissue homogenate by 2.2 times vs control. NOx content in the serum of animals with periodontitis increased by $46.2 \%$ and in the periodontal tissue homogenate - by $74.7 \%$ compared with the control. In rats with periodontitis against hyperthyroidism, NOS activity increased by 3.9 times relative to the control group of animals and by $75.9 \%$ exceeded the rate of rats with periodontitis without concomitant pathology. In rats with periodontitis, against the background of hypothyroidism, the activity of NOS was $29.6 \%$ higher than that of rats with periodontitis without concomitant pathology and 2.9-fold of control.

Conclusions. Experimental periodontitis is accompanied by a marked increase in the intensity of nitroxidergic processes both in the homogenate of periodontal tissues and in the blood. The imbalance of thyroid hormones increases the synthesis of nitrogen (II) oxide in the experimental periodontitis, especially expressed in hyperthyroidism.

KEY WORDS: periodontitis; thyroid hormones; nitrogen (II) oxide. Тернопіль, 46001, Україна, e-mail: shcherba@tdmu.edu.ua. 